УДК 343.8

DOI https://doi.org/10.32837/pyuv.v0i4(39).913

\author{
Д.О. Пилипенко \\ orcid.org/0000-0003-1299-6178 \\ кандидат юридичних наук, \\ доцент кафедри крилінально-правових дисииплін \\ Криворізького навчально-наукового інституту \\ Донеиького державного університету внутрішніх справ
}

\title{
ПРИНЦИП ВЕРХОВЕНСТВА ПРАВА У КРИМІНАЛЬНО-ВИКОНАВЧОМУ ПРАВІ УКРАЇНИ
}

Постановка проблеми. Перманентне реформування вітчизняної правової системи здійснюється в напрямі загальнодержавної євроінтеграційної політики. Цей вектор зумовлює якісні перетворення в усіх сферах галузевого законодавства. Одним із пріоритетних напрямів у цьому контексті є оптимізація кримінально-правової сфери, провідне місце в якій відводиться галузі кримінально-виконавчого законодавства. Удосконалення сфери законодавства здійснюється комплексно, враховуючи структури як загальних, так і прикладних положень цього закону. Фундаментальним напрямом зазначеної нормативної процедури, як вбачається, є визначення змісту та сутності принципів, що покладено в основу побудови i функціонування галузі кримінально-виконавчого законодавства, ключове місце серед яких, безумовно, належить принципу верховенства права. Окреслення ролі, яку відіграє принцип верховенства права, є одним із найбільш дискусійних питань у теорії галузевого права, а особливо галузей кримінально-правового спрямування.

Оцінка стану літератури. Питання, пов'язані з визначенням принципу верховенства права в кримінально-виконавчому праві України, досліджували у своїх роботах такі науковці: О.М. Джужа, О.Г. Колб, В.В. Кондратішина, О.М. Литвинов, Є.С. Назимко, А.Х. Степанюк, В.М. Трубников, I.C. Яковець та інші. Однак, попри наявність достатньої кількості досліджень щодо визначення принципу верховенства права, в кримінально-виконавчому праві досі не окреслено зміст цієї правової категорії та її вплив на сферу виконання й відбування кримінальних покарань загалом.

Метою статті $\epsilon$ аналіз окремих сутнісних аспектів принципу верховенства права в системі засад кримінально-виконавчого права для виокремлення сталої теоретичної позиції щодо місця та ролі цієї засади в структурі як загальних, так і спеціальних принципів кримінально-виконавчого права.

Завдання наданого матеріалу з обраної проблеми. Принцип верховенства права є однією з фундаментальних засад галузевого законодавства, зокрема і кримінально-виконавчого. Важливість цього принципу складно переоцінити, враховуючи його роль у формуванні як загальних, так і спеціальних засад кримінально-виконавчого права. Визначаючи значущість засади верховенства права, всесвітньовідомий дослідник Б. Таманага окреслював цей принцип як «виключний і легітимований політичний ідеал», що поступово поширюється на весь сучасний світ та покликаний якісно змінити як основоположні засади, так і практичний складник системи правового регулювання суспільних відносин у напрямі до загальновизнаних гуманітарних цінностей і критеріїв соціальної ефективності [1, с. 11]. С.П. Головатий, висловлюючи авторський погляд на сутність верховенства права, тлумачить його як «правовладдя». Він зазначає, що цей термін якомога найточніше й найстисліше відтворює сутність англійського «the rule of law». Своєю чергою правовладдя, на думку С.П. Головатого, - це про доктрини, принципи, інститути й процедури, що $€$ вкрай важливими для захисту людини від свавілля держави та наділяють особу правом на людську гідність. Якраз у такому єстві, за словами науковця, багато віків тому воно постало як ідея, а вже в сучасному світі, зокрема в європейському, утвердилось як ідеал, цінність і принцип [2, с. 82].

Одним із актуальних питань є відображення принципу верховенства права в чинному законодавстві України. Чинний Кримінально-виконавчий кодекс України (далі - КВК України) містить ст. 5, в якій визначено принципи кримінально-виконавчого законодавства, виконання і відбування покарань. Законодавцем наведено доволі змістовний перелік засад у зазначеній законодавчій нормі, серед яких наявні як загальні, так і спеціальні принципи. Перелік загальних засад сформовано законодавцем у вигляді законності, справедливості, гуманізму, демократизму, рівності засуджених перед законом, поваги до прав і свобод людини. В наведеному переліку відсутній принцип верховенства права. Про мотиви рішення законодавця щодо невключення верховенства права до загальних засад КВК України можна лише здогадуватися. Це може бути або банальна технічна помилка, або відповідна принципова позиція авторів закону. Якщо це була тривіальна помилка, то логічно передбачити, що в законодавця 3 2003 р. до сьогодні був час на її виправлення, проте представники органу законодавчої юрисдикції не спромоглися на це. Якщо ж це принципова 
позиція законодавця, то такий погляд на формування закону, що регулює пласт правовідносин, пов'язаних із виконанням й відбуванням кримінальних покарань, у контексті відображення його фундаментальних засад є вельми суперечливим. На наше переконання, відображення вищезгаданих загальних засад, які фактично здебільшого $є$ похідними від принципу верховенства права, без безпосередньої фіксації у змісті ст. 5 КВК України самого верховенства права $є$ явним недоліком правової конструкції зазначеної норми КВК України. Проте серед науковців є прибічники позиції невідображення в змісті нормативних актів принципу верховенства права.

Так, В.О. Гацелюк, досліджуючи це питання у сфері кримінального права, зазначає, що принцип верховенства права, як не парадоксально це звучить, містить загрозу саме законності, а цього в кримінальному праві допускати не можна. Верховенство права має бути забезпечене на етапі видання кримінального закону, верховенство якого виступає у вигляді принципу законності кримінального права [3, с. 239]. М.В. Галабала 3 цього приводу також зазначає: малоймовірно, що кримінально-правові відносини колись зможуть регулюватися принципом верховенства права [4, с. 497]. С.Я. Лихова своєю чергою пропонує авторський підхід до вирішення питання щодо визначення засади верховенства права. Так, авторка стверджує, що стосовно кримінального права як галузі, де застосовуються чіткі орієнтири в обмеженні природних прав людини і визначені підстави такого обмеження, єдино правильним кроком є ототожнення принципу верховенства права з принципом верховенства закону [5, с. 42].

Зважаючи на наведений та доволі поширений тезис щодо складності або неможливості застосування принципу верховенства права у практичній діяльності, слід детально висловити особисту авторську позицію з цього приводу. Перш за все, наведені позиції вітчизняних науковців «просякнуті» відвертим скептицизмом щодо прикладних аспектів застосування принципу верховенства права. Враховуючи це, верховенство права розглядається переважно як засада, що притаманна здебільшого утворювачам законів, ніж їх застосовникам. В.О. Навроцький у цьому аспекті вказує, що наявні суперечності між правом та законом мають усуватись у процесі законотворчості, а не застосування закону; правозастосувач не може підміняти собою законодавця; принцип верховенства права адресований насамперед законодавцю; за правозастосування головне - принцип законності [6, с. 23]. В.Г. Гончаренко, розглядаючи питання застосування засади верховенства права у кримінальному процесі, зазначав, що вона не має конкретного нормативного напов- нення етико-правовою вимогою справедливості в регулюванні суспільних відносин. Учений також наголошує, що посилання на засаду верховенства права під час прийняття рішень у суперечливих питаннях не має жодних юридичних наслідків i може виступати як додатковий (часто популістський) психолого-емоційний антураж до владного рішення, яке повинно ухвалюватися лише на основі ретельного вивчення фактичних обставин дійсності і бездоганної юридичної кваліфікації діяння, що вимагає владного врегулювання. Тому справедливими, як зазначає науковець, мають визнаватися всі юридичні рішення, що є переконливими з погляду оцінювання фактичних обставин і конкретної норми закону, незалежно від уподобань, настроїв і переконань окремих осіб [7, с. 6].

Отже, таке дещо «недовірливе» сприйняття місця верховенства права в сучасній вітчизняній правовій сфері є доволі поширеною позицією. Авторська скептика щодо практичної доцільності верховенства права, як вважаємо, здебільшого продиктована відсутністю чіткої та однозначної дефініції принципу верховенства права не лише у вітчизняній науці, а й у міжнародній практиці. Європейський суд із прав людини неодноразово звертав увагу на ситуативність змістовної інтерпретації верховенства права [8, с. 41]. Т.А. Цувіна $з$ цього приводу слушно наголошує, що наразі неабиякий інтерес становить дослідження інтерпретації верховенства права у практиці Європейського суду з прав людини (далі - ЄСПЛ), який послідовно виводить дедалі нові елементи зазначеного принципу під час тлумачення різних статей Конвенції про захист прав людини та основоположних свобод (далі - ЄКПЛ) [9, с. 373]. Однак, як вважаємо, нарікання на відсутність чіткої, конкретизованої дефініції верховенства права, що перешкоджає подальшому її прикладному застосуванню, є вельми дискусійним рішенням. Як вбачається, принцип верховенства права містить в собі надто багато елементів та є доволі «динамічним» за своєю сутністю. Саме ця "динамічність» свідчить про виникнення нових позицій в інтерпретації засади верховенства права, особливо яскраво це явище, як наголошують науковці та як вже зазначалося вище, спостерігається в рішеннях ЄСПЛ. Така сутнісна складність принципу верховенства права фактично робить марними спроби структурувати всі елементні особливості принципу верховенства права в межах конкретизованої термінології. В цьому аспекті слушною $€$ позиція С.П. Головатого, котрий наголошував, що, як довів міжнародний досвід, поняття «the rule of law» взагалі не піддається формальному визначенню [2, с. 48]. До того ж, окремі спроби зробити це наражаються на доволі жорстку критику. В якості прикладу наведемо визначення законодавцем засади верховенства права в межах 
окремих нормативно-правових актів. Так, у ст. 8 КПК України визначена сутність цього принципу в межах кримінального процесуального законодавства, враховуючи яку кримінальне провадження здійснюється 3 додержанням принципу верховенства права, відповідно до якого людина, ïï права та свободи визнаються найвищими цінностями та визначають зміст і спрямованість діяльності держави. Принцип верховенства права у кримінальному провадженні застосовується 3 урахуванням практики Свропейського суду з прав людини. Майже аналогічне визначення засади верховенства права міститься у ст. 6 Кодексу адміністративного судочинства України. Вітчизняний науковець С.П. Головатий критикує наведені законодавцем формулювання верховенства права, наголошуючи, між іншим, на їх невідповідності викладеному в документі Венеційської Комісії 2011 р. європейському стандарту [2, с. 49].

У контексті висловленого також слід навести позицію Конституційного Суду України (далі КСУ) щодо визначення змісту принципу верховенства права, який наголошує, що, відповідно до ч. 1 ст. 8 Конституції, в Україні визнається і діє принцип верховенства права. Верховенство права - це панування права в суспільстві. Верховенство права вимагає від держави його втілення у правотворчу та правозастосовну діяльність, зокрема у закони, які за своїм змістом мають бути проникнуті передусім ідеями соціальної справедливості, свободи, рівності тощо. Одним із проявів верховенства права є те, що право не обмежується лише законодавством як однією з його форм, а включає й інші соціальні регулятори, зокрема норми моралі, традиції, звичаї тощо, які легітимовані суспільством i зумовлені історично досягнутим культурним рівнем суспільства. Всі ці елементи права поєднані якістю, що відповідає ідеології справедливості, ідеї права, яка значною мірою дістала відображення в Конституції України. Таке розуміння права не дає підстав для його ототожнення з законом, який іноді може бути й несправедливим, зокрема може обмежувати свободу та рівність особи [10].

Проте ця позиція КСУ також отримала відповідну критику від представників наукового середовища. С.П. Головатий, аналізуючи наведену позицію КСУ, висловлену ним у рішенні № 15-рп/2004 від 2 листопада 2004 р., наголошував на тому, що КСУ побудував свою юридичну позицію на ідеях, які не мають нічого спільного з науковою доктриною правовладдя ( «the rule of law») всіх часів та її сучасною реалізацією на практиці в межах рішень Свропейського суду з прав людини і напрацьованих Венеційською Комісією досліджень [2, с. 52-53]. За цих умов слід зазначити, що КСУ сформулював сутність принципу верховенства права ще задовго до ухваленої у 2011 р. Венеційською Комісією «Доповіді про верховенство права» (далі - доповідь Венеціанської комісіі), тому піддавати позицію КСУ критиці є дещо недоречним кроком.

Критично поставився до згаданої позиції КСУ щодо визначення верховенства права й I.I. Котюк, який зазначив, що проявом верховенства права $\epsilon$ те, що право не обмежується лише законодавством, а включає в себе й інші соціальні регулятори (зокрема, норми моралі, традиції, звичаї). На думку науковця, КСУ, який запропонував таке розуміння права, мав констатувати перехід правової системи України на англосаксонську правову систему [11, с. 9]. Слід не погодитися з позицією автора з декількох підстав. По-перше, через помилкове сприйняття верховенства права виключно як відображення норм моралі, традицій, звичаїв тощо. Однією з причин подібного сприйняття верховенства права, на наш погляд, є відсутність у праві дефініції «верховенство права». Це зумовлює відповідні дискусії серед науковців не лише щодо змісту відповідного принципу, а й щодо його місця в механізмі регулювання правовідносин системи виконання та відбування кримінальних покарань. За цих умов слід зазначити, що, враховуючи сучасні реалії, відповідна дефініція навряд чи з'явиться в сучасному як національному, так i міжнародному праві. Однак, попри відсутність відповідної термінології, європейське співтовариство вже висловило особистий погляд на зміст верховенства права у вигляді цілком конкретизованих елементів. Як ми вже згадували вище, Венеціанською комісією висловлено позицію щодо обов'язкових змістовних елементів, які у своїй сукупності й відображають верховенство права (п. 41 Доповіді Венеціанської Комісії). Навіть поверхневий аналіз цих елементів у своїй сукупності дає підстави стверджувати, що зміст верховенства права є набагато ширшим за запропоновану інтерпретацію його I.I. Котюком. Загалом зміст зазначених елементів - не лише про соціальні, людські традиції та звичаї як пріоритетні елементи правового регулювання в суспільстві. Ці «структурні одиниці» - про цілком реальні засади, а не про ефемерні елементи, які складно достовірно визначити. Також зміст цих елементів може бути реалізований виключно за допомогою позитивного права в державі, тобто через відповідну нормативну регламентацію та наявність правового механізму, який забезпечуватиме дієве, а не лише декларативне існування цих засад. Крім цього, враховуючи змістовний складник елементів верховенства права, виникнення суперечностей між прикладними аспектами реалізації засад законності та верховенства права завжди матиме інваріантний наслідок - це фактичне визнання неправової природи законного акта, тобто його нікчемності.

По-друге, I.I. Котюк фактично протиставив наявну в Україні романо-германську систему права англосаксонській. У цьому аспекті слід зазначити, 
що доповідь Венеціанської комісії містить певні роз'яснення, які відображені у Вступі цієї Доповіді: 1) поняття «верховенство права» («rule of law») разом із поняттями «демократія» та «права людини» - це три підвалини, на яких була заснована Рада Європи. У подальшому це поняття знайшло своє схвалення у преамбулі Європейської Конвенції з прав людини; 2) воно також закріплено у низці міжнародних документів щодо прав людини та в інших документах, які містять визначені стандарти; 3) передумовою цієї доповіді виступає Резолюція 1594 (2007р.) Парламентської Асамблеї Ради Європи («Принцип верховенства права») [12, с. 169]. Отже, наведені пункти Доповіді цілком свідчать про загальноєвропейську позицію щодо визначення верховенства права, тож дорікання I.I. Котюка вищому органу законодавчої юрисдикції нашої держави щодо переходу вітчизняної правової системи на стандарти англосаксонської системи права, спираючись на запропоновану інтерпретацію верховенства права, здійснену КСУ, є некоректним твердженням. У цьому аспекті слід погодитися з А.Б. Дідікіним, який вказував, що, зважаючи на процеси глобалізації та європейської інтеграції, протиставляти англосаксонську і романо-германську правові системи немає сенсу. Це підтверджується взаємним впливом таких систем і формуванням нових, інтегрованих [13]. До того ж, зазначене протиставлення взагалі позбавлене сенсу, оскільки сучасна концепція верховенства права, не заперечуючи обов'язковості законодавства, передбачає, що протиставлення останнього судовій правотворчості виникає лише в тих виключних випадках, коли закон сам по собі (чи за його застосування в конкретній ситуації) зумовлюе явну несправедливість, призводить до порушення основоположних прав і свобод людини або посягає на інші фундаментальні цінності демократичного суспільства [14, с. 132]. Слід погодитися з наведеними позиціями науковців, які справедливо наголошують на недоцільності ведення мови щодо протиставлення між собою природно-правових та позитивістських концепцій, що начебто можуть бути наслідком необгрунтованого нав'язування «чужорідної» англосаксонської концепції про верховенство права. Навпаки, автори Доповіді Венеціанської комісії у п. 41 Доповіді визначили ключові аспекти конвергенції природно-правової та позитивістської концепцій. Про це свідчить пп. А п. 41 Доповіді, відповідно до якого законність є одним із елементів верховенства права. Отже, автори цієї доповіді остаточно визначили абсолютно позитивістське явище у вигляді законності як невід'ємний елемент верховенства права, при цьому обов'язкове дотримання законності сприятиме утвердженню та забезпеченню верховенства права, а не навпаки. Європейське співтовари- ство демократичних держав фактично остаточно визначилося з основоположенням верховенства права у внутрішніх та міждержавних відносинах. Позиція національного законодавця в умовах незмінного євроінтеграційного вектора державного розвитку має корелюватися 3 позицією держав Європи. До того ж, вітчизняний законодавець визначив, що національні суди застосовують під час розгляду справ Конвенцію про захист прав людини і основоположних свобод та практику ЄСПЛ як джерело права (ст. 17 ЗУ «Про виконання рішень та застосування практики Європейського суду 3 прав людини»). Таким чином, наведене питання щодо пріоритетності верховенства права і незмінності правового курсу з належної реалізації зазначеної засади є аксіоматичним фактом для національної правової системи.

Аналізуючи позиції науковців щодо скептицизму практичної реалізації засади верховенства права, слід зазначити, що це здебільшого стосується критеріїв дотримання прав людини та реалізації таких прав в умовах конкуренції публічних і приватних інтересів. Прибічники позитивістської законності відстоюють позицію щодо домінанти формалізованого закону. Натомість є і науковці, які віддають провідне місце в сучасній правовій системі природно-правовій концепції та керівному положенню верховенства права. Навіть наявна перспектива використання інтегрального підходу до кореляційного, одночасного врахування як приватно-правових, так і публічних інтересів не $€$ позитивним складником у питанні встановлення «балансу сил» між зазначеними інтересами. Вирішенню цієї суперечки цілком може допомогти підхід, запропонований німецьким правознавцем і політиком Г. Радбрухом, так звана «формула Радбруха». Суть позиції науковця полягає в тому, що під час конфлікту (неявного, неочевидного для всіх) позитивного права і справедливості (тобто природного права) пріоритет, як правило, має надаватися позитивному праву; однак у тих випадках, коли зміст законів є настільки несумісним зі справедливістю, що фактично повністю її заперечує, судді та інші особи повинні утриматися від застосування таких неправових законів [14, с. 136]. На наше переконання, така формула цілком може стати фактором збалансування позитивістських і природних концепцій у межах прикладної реалізації принципу верховенства права. Це стосується і галузі кримінально-виконавчого права.

Висновки. Принцип верховенства права є ключовим у системі засад кримінально-виконавчого права. Його фундаментальність визначена теорією та практикою європейського співтовариства. Ця засада включає в себе обов'язкові елементи, які фактично визначають першочерговість цього правового принципу відносно загальних і спеціальних засад кримінально-виконавчого права. Одним із 
головних аспектів теорії кримінально-виконавчого права є остаточне визначення цієї засади в межах чинних кримінально-виконавчих норм та окреслення правового механізму їі застосування. Перспективою подальших досліджень в цьому напрямі $є$ коректне теоретичне комплексне сприйняття всіх елементів, що утворюють верховенство права, відповідно до висновків Венеціанської комісії, а також вироблення належного позитивного правового механізму для реалізації зазначених елементів.

\section{Jimepamypa}

1. Таманага Б. Верховенство права: історія, політика, теорія / пер. з англ. А. Іщенка. Київ : Видавничий дім «Києво-Могилянська академія», 2007. 208 с.

2. Головатий С.П. «Верховенство права» не працює: коментар до тексту документа Венеційської комісії «Доповідь про правовладдя». Право України. 2019. С. 40-82.

3. Беніцький А.С., Гуславський В.С. Кримінальне право. Загальна частина : підручник. Київ : Істина, 2011. $1112 \mathrm{c}$.

4. Галабала М.В. Розвиток вчення про кримінальний закон в кримінально-правовій науці. Держава і право. 2008. Вип. 40. С. 494-504.

5. Лихова С.Я. Верховенство права Європейського Союзу як одна з причин реформування кримінального законодавства України : збірник наукових праць. Миколаїв : Іліон, 2016. С. 40-43.

6. Навроцький В.О. Кримінальне право і кримінальне законодавство: співвідношення понять. Право України. 2011. № 9. С. 20-24.

7. Гончаренко В.Г. Засади верховенства права та законності кримінального провадження в плані здійснення захисту. Вісник Академї̈ адвокатури України. 2013. Вип. 3. С. 4-10.

8. Рабінович П.М. Верховенство права в інтерпретації Страсбурзького Суду та Конституційного Суду України. Вісник Конституиійного Суду України. 2006. № 1. С. $37-46$.

9. Цувіна Т.А. Принцип верховенства права у практиці європейського суду з прав людини. Часопис Київ ського університету права. 2019. № 4. С. 373-379.

10. Верховенство права. Конституційний Суд України. URL: https://zakon.rada.gov.ua/laws/show/ v015p710-04\#Text

11. Котюк I.I. Верховенство права як морально-етичний імператив. Юридичний вісник Украйни. 2017. № 19-20. С. 9 .

12. Доповідь Європейської комісії «За демократію через право». Верховенство права. Право Украӥни . 2011. № 10. С. 168-184.

13. Дідікін А.Б. Рішення Європейського суду 3 прав людини у національній правовій системі. URL: www.justinian.com.ua/article.php?id=3113

14. Дудоров 0.О., Мазур М.В. Реалізація принципу верховенства права у випадках застосування закону про кримінальну відповідальність: постановка проблеми, міжнародний і зарубіжний досвід. Юридичний на уковий електронний журнал. 2017. № 5. С. 130-141.

\section{Анотація}

Пилипенко Д. О. Принцип верховенства права у кримінально-виконавчому праві України. - Стаття.

У статті розглянуто питання, пов'язані з визначенням принципу верховенства права в системі засад кримінально-виконавчого права України. Зосереджено увагу на факторі визначення засад у межах чинного кримінально-виконавчого законодавства. Наголошено на особливості конструкції відповідної норми закону, що визначає перелік принципів КВК України. Висловлено авторську позицію про те, що невідображення в системі засад кримінально-виконавчого законодавства принципу верховенства права є відповідним недоліком законодавчої конструкції згаданої норми закону. В статті висловлено позицію щодо наявного сприйняття законодавцем системи норм кримінально-виконавчого права. Проаналізовано авторські погляди на визначення сутності верховенства права в межах окремих галузей права кримінально-правового спрямування. Наведено позицію Конституційного Суду України з цього питання. Проаналізовано погляди науковців на таку позицію КСУ. Висловлено авторську думку щодо деяких із них. Аргументовано, що сучасне змістовне сприйняття верховенства права як правового принципу не є похідним від досвіду науковців англосаксонської правової системи, а є надбанням сучасної європейської правової доктрини, що поєднує в собі також і концепції романо-германської правової системи. У статті наголошено на безперспективності визначення верховенства права в контексті контрастного сприйняття правової дивергенції зазначених правових систем. Акцентовано увагу на важливості конвергенції визначених правових систем для визначення сутності принципу верховенства права. У статті висловлено позицію щодо доцільності застосування формули Радбруха з метою вирішення суперечностей у контексті конкурентних умов між публічними та приватно-правовими інтересами під час практичної реалізації принципу верховенства права в межах чинного кримінально-виконавчого права.

Ключові слова: принцип верховенства права, засада законності, романо-германська правова система, англосаксонська правова система, формула Радбруха.

\section{Summary}

Pylypenko D. O. The principle of the rule of law in the criminal executive law of Ukraine. - Article.

The article considers issues related to the definition of the rule of law in the system of principles of criminal executive law of Ukraine. The focus is on the factor of determining the principles within the current criminal executive legislation. Emphasis is placed on the peculiarities of the construction of the relevant norm of the law, which determines the list of KEC principles. The author's position is expressed that the non-reflection in the system of principles of criminal-executive legislation of the principle of the rule of law is a corresponding shortcoming of the legislative construction of the mentioned norm of the law. The article expresses the position on the current perception of the legislator of the system of criminal executive law. The author's views on determining the essence of the rule of law within certain branches of criminal law are analyzed. The position of the Constitutional Court of Ukraine on this issue is given. The author's positions of scientists in relation to the given position of the CCU are analyzed. The author's view on some of them is expressed. It is argued that the modern meaningful perception of the rule of law as a legal principle is not derived from the experience of scholars of the Anglo-Saxon legal system, but is also a property of modern European legal doctrine, which also combines the concepts of Romano-Germanic legal system. The article also emphasizes the futility of determining the rule of 
law in the context of a contrasting perception of the legal divergence of these legal systems. The importance of the convergence of these legal systems to determine the essence of the rule of law is emphasized. The article expresses the position on the expediency of applying the Radbruch formula for resolving contradictions in the context of competitive conditions between public and private interests, during the practical implementation of the rule of law within the current criminal executive law.

Key words: principle of rule of law, principle of legality, Romano-Germanic legal system, Anglo-Saxon legal system, Radbruch's formula. 